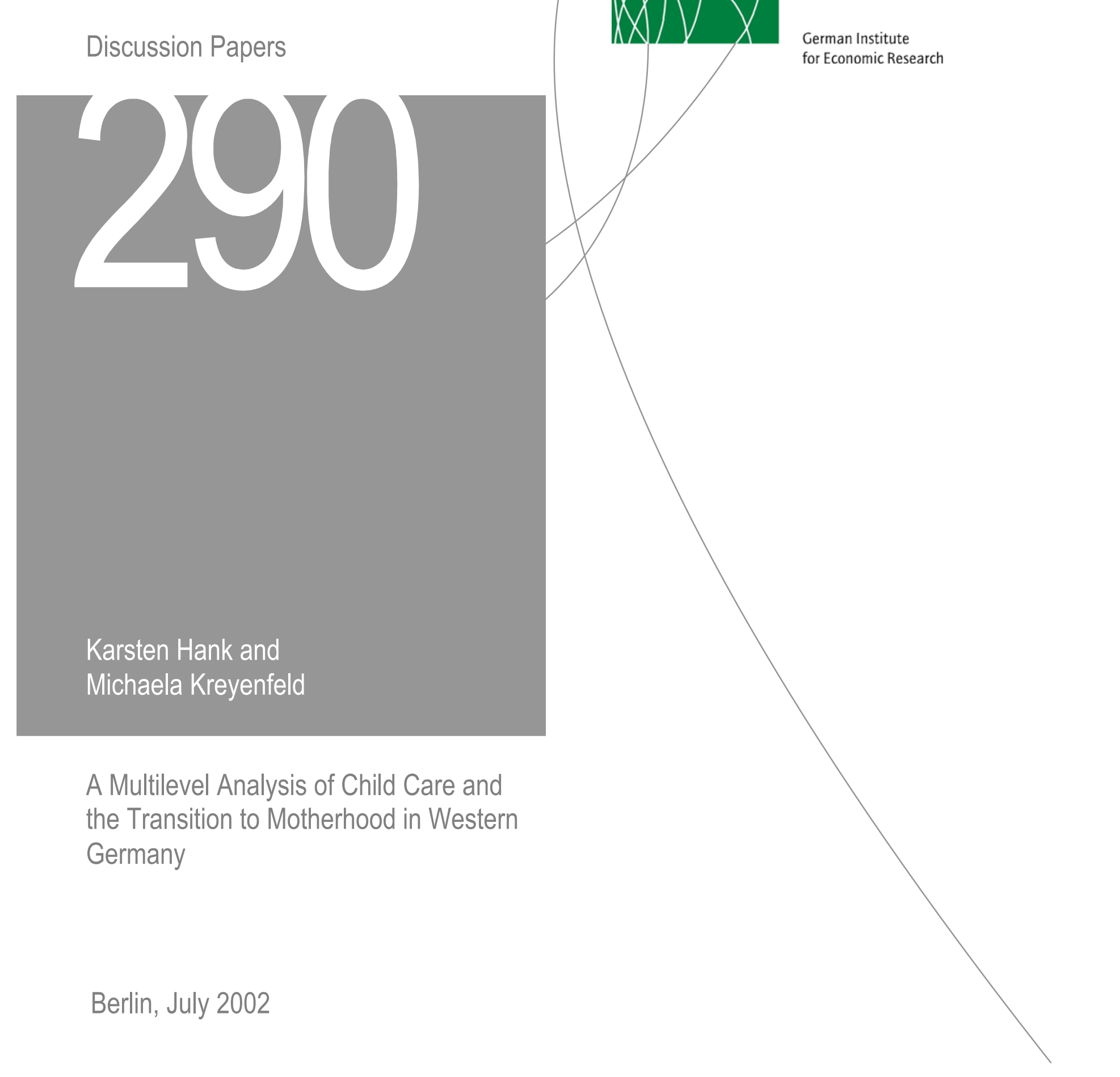


Opinions expressed in this paper are those of the author and do not necessarily reflect views of the Institute.

\section{DIW Berlin}

\section{German Institute}

for Economic Research

Königin-Luise-Str. 5

14195 Berlin,

Germany

Phone +49-30-897 89-0

Fax +49-30-897 89-200

www.diw.de

ISSN 1619-4535 


\title{
A Multilevel Analysis of Child Care and the Transition to Motherhood in Western Germany
}

\author{
Karsten Hank and Michaela Kreyenfeld ${ }^{\star}$
}

$\underline{\text { July } 2002}$

\begin{abstract}
In this paper, we take a multilevel perspective to investigate the role of child care in the transition to motherhood in Germany. We argue that in the European institutional context the availability of public day care and informal child care arrangements should be a central element of the local opportunity structure regarding the compatibility of childrearing and women's employment. Using data from the German Socio-Economic Panel, we apply a multilevel discrete time logit model to estimate first birth risks of western German women. While we find that access to informal care arrangements increases the probability of entering parenthood, we do not find any statistically significant effect of the public day care provision. This result probably points to shortcomings in the specific institutional set-up of the German daycare regime, and to the existence of potentially relevant unobserved dimensions of child care.
\end{abstract}

Keywords: child care, fertility, multilevel analysis, Germany

\footnotetext{
^ Authors' correspondence address: Max Planck Institute for Demographic Research, Doberaner Str. 114, 18057 Rostock, Germany. Email: hank@demogr.mpg.de; kreyenfeld@demogr.mpg.de.

This paper has been presented at the Population Association of America 2002 Annual Meeting in Atlanta, Georgia. We thank Arnstein Aassve and Pau Baizán for valuable econometric advice. Kind support of the GSOEP-Team during a stay at the DIW Berlin is gratefully acknowledged.

The views expressed in this paper are our own. They do not necessarily reflect the views of the Max Planck Institute for Demographic Research.
} 


\section{INTRODUCTION}

From the mid-1960s onwards, fertility rates in industrialized countries declined rapidly, reaching a persistent below-replacement level soon after. Women's increasing educational attainment, their growing labor market participation, and higher career aspirations are widely believed to be main forces underlying this development (e.g., Becker 1993; Hirschman 1994; Oppenheimer 1994). Many empirical studies have confirmed a negative relationship between female education or employment on the one hand, and fertility on the other hand. Analyzing macro-level data from the US, Butz and Ward (1979), for example, show that women's wages are negatively correlated with fertility rates. Also at the micro level, a negative correlation between female wages or their educational attainment and fertility has been reported repeatedly (e.g., Heckman and Walker 1990: 1439; Merrigan and St. Pierre 1998: 41). Brewster and Rindfuss (2000: 271) thus conclude that “women's labor force participation lies at the heart of most explanations of fertility and fertility change" and that the inverse "association between fertility and women's labor force activity reflects the incompatibility between caring for children and participation in economically productive work that typifies industrialized societies.”

However, this association has never been as consistent as has been claimed sometimes. A growing body of research even suggests a changing, now positive relationship between female education or employment on the one hand, and fertility on the other hand (e.g., Ahn and Mira forthcoming; DeWit and Ravanera 1998: 60; Ermisch 1989: 93; Hoem 2000; Hoem and Hoem 1989: 52; Kravdal 1992). These findings might point to social contexts that allow women to combine childrearing with a continuous employment career. Access to affordable child care is frequently considered 
as one of the most important structural conditions to solve the compatibility problem (e.g., Rindfuss and Brewster 1996: 262; Meyers et al. 1997: 119).

Although the role of child care in fertility decisions is often acknowledged implicitly, it has rarely been investigated directly in empirical models of fertility. One of the few studies in this context is the one by Lehrer and Kawasaki (1985), which suggests that the availability of care by relatives increases US parents' desire to have another child. Mason and Kuhltau (1992) find evidence for child care constraints on women's employment and fertility in a sample of Detroit-area mothers. For Norway, Kravdal (1996) reports a stimulating effect of an increasing supply of public day care for children aged 0 to 3 on women's probability to advance to parity three. However, there is no further increase in birth probabilities at coverage levels above 10 percent, and the day-care-effect becomes insignificant when aggregate female employment is accounted for in the model. Most recently, Del Boca (2002) detects a positive impact of the availability of public day care on childbearing in the Italian lowest-low fertility setting.

The present paper investigates the role of child care availability for women's entry into motherhood in Germany. First, we discuss the relationship between female employment, fertility, and child care from a theoretical point of view, stressing the need for a multilevel perspective. Later sections provide a concise overview of day care for children in Germany and a description of the empirical procedure. Individual level data on women living in western Germany during the period 1984 to 1999 are taken from the German Socio-Economic Panel (GSOEP), which we link with information on the regional day-care provision. Due to data limitations, we are unfortunately not able to include the eastern states of the Federal Republic into the multivariate analysis. 
Applying multilevel discrete-time logit models, we estimate the impact of the availability of public day care and informal child care arrangements on the transition to the first child. The final section concludes.

\section{FEMALE EMPLOYMENT, FERTILITY, AND CHILD CARE}

Since primarily women are still responsible for rearing children, they often cannot pursue a regular employment career once they have become a mother (see Joshi 1998 for a discussion). It has been argued, though, that egalitarian gender roles, flexibility in work schedules, and particularly adequate child care opportunities may constitute a social context, in which women's participation in the labor market and childrearing are compatible (e.g., Ellingsæter and Rønsen 1996).

The more the traditional division of household responsibilities diminishes and the more likely it is that fathers take child care responsibilities (e.g., Casper and O'Connel 1998), the less strong should be the negative correlation between fertility and female employment. Particularly public policies that encourage or discourage existing malebreadwinner models play an important role here (e.g., Meyers et al. 1997: 137; Sainsbury 1997: 185). With regard to the relevance of labor market institutions, Glass and Estes (1997) furthermore point to the potential of reduced work hours, schedule flexibility, and workplace social support for an improved family functioning in dualearner households (see also Presser 1989). However, it is an increase in the use of outof-home child care which is supposed to be the most important factor for recent changes in the employment-fertility nexus (e.g., Ahn and Mira forthcoming; Meyers et al. 1997; Rindfuss and Brewster 1996). Given that non-parental day care for children is socially 
accepted, economically affordable, and readily available, motherhood and employment would no longer be incompatible. Against this background, female employment would cease to suppress fertility.

The social and individual acceptance of non-parental care is a crucial issue. Parents may be concerned that out-of-home day-care could harm the wellbeing of their child, because the quality of public day-care might be perceived as insufficient (e.g., Blau 2001; Blau and Hagy 1998). Moreover, mothers are often confronted with restrictive attitudes towards employment after childbirth as well as with strong normative expectations that prevent them from using out-of-home care, particularly for children at younger ages (e.g., Knudsen and Wærness 2001; Rindfuss and Brewster 1996: 277).

As regards the affordability of care, economic models of labor supply have greatly contributed to the understanding of the role of child care costs in women's employment decisions (e.g., Conelly 1992; Heckman 1974). In these models, the costs of care are treated as a decrease in the female net wage rate, which is supposed to reduce women's propensity to work in the market. Along the same line one could argue that child care costs lead to higher overall costs of children (given that the woman seeks employment), which should result in lower fertility. However, child care costs need not necessarily lead to lower birth rates of employed women (e.g., Blau and Robbins 1989). Although women who combine childrearing and employment may encounter a "wage penalty for motherhood" (Budig and England 2001), working mothers still have larger economic resources to support a family than those who stay at home.

While focussing on child care costs might be reasonable for an analysis of the situation in the US, where parents have access to a functioning private market for care 
(e.g., Riley and Glass 2002; Rindfuss et al. 1996: 280), it is insufficient to describe the European setting, where day care is predominantly public and private markets for child care barely exist (e.g., Esping-Andersen 1999: 55ff.; Stier et al. 2001: 1735). In such an institutional context, the availability of public day care and informal child care arrangements should gain importance over the monetary costs of care. The supply of children's day care hence becomes a central element of the local opportunity structure.

However, a high quantitative coverage of public day care alone does not necessarily provide a favorable opportunity structure to combine child rearing and employment. The proximity of day-care centers and the flexibility of the opening hours are important additional parameters in this regard. If public day care is only provided during rigid opening hours or day care centers are inconveniently located, even a high coverage of public day care is relatively ineffective in fostering maternal employment or fertility. A similar matter applies with regard to the quality of day care. Parents might be unwilling to use a public day care institution, because the quality of care is perceived as beyond acceptable levels. Although private care arrangements might provide a satisfying level of child care quality, such care arrangements might be too expensive for many income groups (e.g., Blau 2001; Blau and Hagy 1998). Furthermore, child care needs are not homogeneous or static (Glass and Estes 1997: 293). If public day care policies focus on care for children of particular ages only (for example pre-school children, as it is the case in western Germany), it might be ineffective in resolving compatibility problems in the long term. Public day care might then be of little support for parents with children of different age groups.

Our empirical models explicitly recognize the multilevel structure of the link between regional opportunity structures, namely child care infrastructure, and individual 
fertility decisions (see Hank 2002a; Teachman and Crowder 2002 for a general discussion). We use western Germany as an example in the analysis. The following section therefore provides a brief overview of the German 'day-care regime'.

\section{CHILDREN'S DAY CARE IN GERMANY}

The German day-care system is generally speaking characterized by a high level of quality regulation and a dominance of publicly provided child care (see Kreyenfeld et al. 2001 for a detailed analysis). Public day care is primarily financed and planned by the municipalities, which either supply child care slots themselves, or allocate subsidies to non-profit organizations, which in turn provide day-care facilities. The costs of care to parents (Elternbeiträge) are relatively low, particularly since day-care fees should be charged according to the household income of the parents (Kreyenfeld et al. 2001). Reliable and representative data on the actual amount of Elternbeiträge are hard to come by. However, the state of Nordrhein-Westfalen legislated regulations stating that parents in a middle income range (i.e. with an annual net household income of about $30,000 €$ ) pay $140 €$ for the Krippe (i.e. children up to the age of 3), $70 €$ for all-day care in Kindergarten (i.e. pre-schoolers), and $60 €$ for the Hort (i.e. school-age children) per month (Gesetz über Tageseinrichtungen für Kinder NRW 2002). This is roughly 2 to 6 percent of the household income and hence substantially below the amount US-parents usually have to spend for children's day care (see Giannarelli and Barsimantov 2000; Smith 2000).

Since the public provision of care is a municipal responsibility in the first place, distinct regional variations can be observed, where rural districts are generally at a 
disadvantage, particularly regarding slots for infants and for school-age children (Kreyenfeld and Hank 2000; Tietze et al. 1993). Profoundest differences in the provision of public day care have continued to exist between eastern and western Germany after unification in 1990 (Hank et al. 2001; see Table 1). In western Germany, part-time care in Kindergarten, i.e. for pre-schoolers aged 4 to 6, became established in the 1970s, and since 1996 all children aged 3 to school-age are entitled to a slot in a public day-care center for half of the day (Colberg-Schrader and Zehnbauer 1996). However, while in 1999 about 85 percent of the pre-school children attended a Kindergarten (as compared to 30 percent in 1960), care for children up to the age of 3 in the so called Krippe, and care for school-age children in the Hort has remained at an extremely low level of clearly less than 10 percent in western Germany. The same is true for full-time care, which is used by only 20 percent of the children in Kindergarten, and is virtually non-existent for younger children or those who are of school-age.

\section{[Table 1 about here]}

In the eastern Bundesländer, on the other hand, not only the provision of slots for infants and school-age children has remained many times higher than in the West, but also full-time care is still widely available. Throughout the history of the GDR, the central government strongly supported and heavily subsidized institutional day care for children of all ages. It was expected that the introduction of the western German political, legal, and economic system would be accompanied by a clearly reduced availability, and substantially increasing costs of child care in the East (e.g., Kistler et al. 1993). However, although many day-care facilities were shut down, children's day care in eastern Germany is still readily available. One main reason for the sustained high provision of public day care in the eastern Bundesländer is the dramatic decline in 
birth rates in the first years after unification (e.g., Kreyenfeld 2000). It has been furthermore argued that in the years following unification high female unemployment rates reduced the demand for out-of-home care (Engelbrech and Jungkunst 1998). At least in the long run, though, the number of child care slots in the East is likely to be further reduced, which would lead to a situation in which eastern German mothers would no longer be in a better position to combine childrearing and gainful employment than their western counterparts (see Hank et al. 2001; Kreyenfeld et al. forthcoming).

Public day care in (western) Germany is primarily designed to provide highquality care that contributes to children's early education, not to foster the compatibility of the mother and worker role. Opening hours in Kindergarten, for example, are so rigid that mothers often cannot event engage in part-time work. In contrast to other industrialized countries, where public schools provide de facto child care for mothers of school-aged children (e.g., Gornick et al. 1997), the German school system provides only very limited alternative custody for dependent children, since schools are open in the morning hours only and do not start or end the same time every day.

The restricted supply of children's day care is consistent with other family policies in Germany, which support the traditional male-breadwinner model. The German income-tax system, for example, provides a progressive tax schedule and the opportunity for married couples to file their taxes jointly, which is widely believed to favor the woman's withdrawal from the labor market. Moreover, parental leave regulations provide a 'generous' three year period of leave, which is combined with low parental leave benefits, though. This long parental leave period is widely viewed as contributing to a devaluation of human capital, and the income replacement level is 
regarded as too low to encourage fathers to take up the leave (e.g., Meyers et al. 1997: 137; Sainsbury 1997: 186).

Against the background of these institutional constraints, it might be comprehensible that most West German mothers choose to interrupt or to give up their employment career to raise children (e.g., Büchel and Spieß 2002; Drobnic 2000). This might also explain, why despite the restricted supply of public day care, no significant private day care market has evolved in Germany yet. However, to fully understand the non-existence of a private market of care, other restrictive institutional constraints need to be considered, too. The German government is not only reluctant to promote the use of commercial child-minders, for example, but it also sets high market barriers of entry for commercial providers of day care (see Kreyenfeld et al. 2001; Spiess 1998 for a detailed discussion).

Table 2 displays the use of supplementary (i.e. non-parental and non-public) child care arrangements in Germany in 1997. It shows that child minders (Tagespflege) or commercial day-care centers play an inferior role only, even for working mothers. However, up to 40 percent of all women and even half of all working mothers regularly rely on friends or relatives as additional providers of care (see also Presser 1989: 529). For the functioning of such child care arrangements, grandparents play a particularly important role (e.g., Engelbrech and Junkunst 1998; Smith 2000).

[Table 2 about here]

Given the dominant position of care in social networks and public day care, the compatibility of women's employment and fertility in Germany should mainly depend on access to these care arrangements. Given the absence of a private market for care, the 
costs of care might be of secondary importance only. In line with our theoretical considerations, we treat the availability of care as a multilevel issue, influencing the woman's employment and fertility decision through the local opportunity structure. We address this empirically by applying a multilevel model on the transition to the first child, using the availability of public day care and care by grandparents as independent variables. Due to data limitations, we have to restrict the analysis to the western states of Germany. Furthermore, it is important to note, that we are only able to address the availability of these care arrangements. Other previously mentioned dimensions of care, such as the quality, flexibility or acceptability of day care can unfortunately not be addressed with our data.

\section{DATA AND METHOD}

\section{Data and Variables}

The individual level data used in this paper were made available by the German SocioEconomic Panel Study (GSOEP) at the German Institute for Economic Research (DIW Berlin) (see SOEP Group 2001 for a description of the dataset). The survey was started in the western states of Germany in 1984 and is conducted annually since then. The GSOEP provides longitudinal socio-economic information on more than 7,000 households (including an oversample of foreign-headed households) and 14,000 individuals. We link the GSOEP with information on the 328 western German Kreise, i.e. district-level data, which we derive from the DJI Regionaldatenbank (see http://www.dji.de for details). This comes fairly close to the municipal level, where decisions about the supply of public day care are made. 
The observation period covers all waves of the panel till 1999. Only respondents from the two original GSOEP subsamples are included in the analysis, i.e. western Germans and foreigners from Greece, Italy, Spain, Turkey, and former Yugoslavia, who already lived in Germany in 1984. Our final sample consists of 2,892 women who are observed from age 20 onwards. The upper age limit is 35 years. Since each individual is allowed to contribute multiple observations, this leads to 13,537 individual records. The number of observed first births in the period 1984 to 1999 is 1,071 . Further descriptive sample statistics are displayed in Table 3.

[Table 3 about here]

The binary dependent variable equals one in case of the occurrence of a first birth within a one-year interval in the period 1984 to 1999 . A number of standard sociodemographic control variables is considered in the analysis. Since a non-linear effect of age is assumed, age and age squared are used in the regression. Education is treated as a time-varying covariate, measured by a set of binary variables, indicating the respondent's highest educational degree in each wave. We distinguish between being in education, having no degree, a vocational degree (reference category), or a university degree. A time-constant binary variable finally controls for possible differences in the fertility behavior of Germans and foreigners. We do not include the woman's marital status as a control variable, since particularly in the western German context, there is good reason to believe that first birth and marriage are part of the same process (e.g., Hank 2002b; Konietzka and Kreyenfeld 2002). In other words, marriage is endogenous to fertility and should therefore be excluded from the model. 
With regard to institutional child care, one should ideally not only take into account the quantity of available public day care, but also information on the proximity of day-care centers and their opening hours, e.g. whether care is provided during lunchtime and school holidays. Since such data are not readily available, we merely consider the number of slots per 100 children aged 3 to 6 in the woman's residential district. Our analysis is limited to care in Kindergarten, since information on the supply of slots for younger children is not available for all Kreise. Moreover, the DJI Regionaldatenbank provides regional day care provision rates for two points in time only, namely 1986 and 1994. The observation period is therefore again divided into two halves, from 1984 to 1991, and from 1992 to 1999, respectively. The child care provision rates are then assumed to be time-constant within each of the two periods, and are allowed to vary only between the two periods defined above.

To indicate the potential availability of informal care for children by relatives, we make use of a binary variable that equals 1 , if the respondent's parents live in the same town, 0 otherwise. The GSOEP provides this information for the years 1991 and 1996 only. Therefore we have to assign the 1991 value to all previous years, and the 1996 value to all years from 1992 onwards, i.e. we treat the variable as time-constant within each of these two periods. For all respondents who did not participate in the survey in 1991 or 1996, respectively, the variable is set to 0 ; a flag variable in the regression controls for these imputed values.

Unfortunately, there are no data on the supply of commercial child care (child minders, baby-sitters, private day-care centers, etc.) available for our analysis. However, since commercial providers account only for a very small share of the total amount of child care in Germany, we do not expect a significant bias in our analysis. 


\section{Multilevel Discrete-Time Logit Models}

To analyze the transition to the first child, we apply a discrete-time event history model, where the hazard rate is specified as a logistic regression function (e.g., Allison 1982). If the conditional probabilities that an event occurs at time $t$, given that it has not already occurred, are sufficiently small (i.e. not larger than 0.1), the logit model provides a good approximation to the continuous time proportional hazards model (e.g., Yamaguchi 1991). In the present case, the log odds that a woman experiences a first birth within the one-year interval $t$ is

$$
\log \left[p_{i j t} /\left(1-p_{i j t}\right)\right]=b_{0}+b_{1} x_{i j}+b_{2} z_{i j t}+b_{3} w_{j t}+u_{0 j}
$$

where $p_{i j t}$ is the probability of individual $i$ in region $j$ to have a birth in year $t, b_{0}$ is the intercept constrained to be equal across all years, $x_{i j}$ is a vector of time-constant explanatory variables, while $z_{i j t}$ and $w_{j t}$ are vectors of time-varying explanatory variables at time $t$. Since a birth of a specific order is a non-repeatable event, no individual-level unobserved heterogeneity factor can be identified. However, a regional-level random component $u_{0 j}$, which is assumed to be normally distributed with the expected value 0 and the variance $\sigma_{u}^{2}$, is included to account for the multilevel structure of our model.

If individual and aggregate level variables are jointly analyzed in a single statistical model, the standard assumption of independent disturbances is critically violated, which may result in inefficient estimates of the macro level parameters and downwardly biased estimates of their standard errors (e.g., Hox and Kreft 1994). To avoid this, a regional random term is introduced here, where the same $u_{0 j}$ applies to all observations in a particular region. It captures otherwise unobserved regional effects 
and accounts for the correlation between individuals nested within the same context. For a thorough discussion of discrete-time multilevel hazard models see Barber et al. (2000).

Discrete-time logit models use multiple observations for each individual in the sample, i.e. each time unit during which an individual is observed contributes a separate and independent observation to the input data. For each of these observations, the dependent variable is coded 1 if the event occurs, 0 otherwise. The results of the logistic regression may then be exponentiated to obtain odds ratios, which can be interpreted in the sense that, controlling for other covariates, an increase in one unit of $x_{i j}$, for example, increases (or decreases) the odds of having the event $\exp \left(b_{1}\right)$ times.

\section{REGRESSION RESULTS}

We estimated two different main models: the first one is a 'traditional' regression model without unobserved heterogeneity (Model 1), while the second one is a multilevel model that includes a regional random effect (Model 2). The regression results are displayed in

Table 4. In addition we estimated a number of alternative specifications (including interaction terms, for example), whose results we do not discuss in detail. The respective tables can be found in the Appendix.

Socio-demographic control variables. The coefficients of the individual-level control variables come out with the anticipated signs in both models. To begin with, the age function has a concave shape and is highly significant. Turning to the educational variables, we find that being in education strongly reduces a woman's propensity to have a first birth. Women who terminated education without any secondary 
qualifications (i.e. without vocational certificate or university degree) encounter significantly higher first birth risks. Compared to women with a vocational degree, their risk of entering motherhood is 30 percent higher, suggesting a faster transition rate to the first child for women with low employment chances. There is no statistically significant difference between having a vocational training certificate or a university degree, though. Finally, the birth risk increases by roughly 30 percent, if foreign women are considered. These results do not change when we control for regional-level unobserved heterogeneity in Model 2.

Child care variables. Consistent with our theoretical considerations, the coefficient of the continuous variable measuring the availability of public day care in Kindergarten has a positive sign, but turns out to be very small and insignificant (in the table it is multiplied by 100 to improve its display). Controlling for regional-level unobserved heterogeneity in Model 2 results in an even further reduction of the child care effect. The availability of informal care, on the other hand, has a strong and significantly positive impact on the transition to motherhood. If the respondent's parents live in the same town, her first birth risk increases by roughly 20 percent. Some of this effect might also be attributed to other longstanding social networks, which are more likely to be available for child care purposes, if the woman still lives in her parents' vicinity.

We also tested alternative specifications of the public day-care variable (see Appendix). A binary indicator that equals 1, if the child care provision rate is above 95 per cent becomes insignificant, once we control for unobserved regional heterogeneity (Table A1). Since parents might change their subjective perception of child care availability in discrete steps rather than continuously (cf. Kravdal 1996), we tried 
several categorical specifications, using different threshold levels (such as a provision rate above 60 percent, above 70 percent, etc.) (Table A2). This did not provide any robust results pointing to a significant effect of public day care on the risk of having a first child either. Interacting the binary public day-care indicator with the family network variable (Table A3) shows that the positive effect of the availability of informal care is independent of a region's level of child care supply.

Based on the assumption that a higher career orientation increases the need for non-parental care options, we finally interacted both child care variables with the woman's educational attainment (Table A4 and Table A5). The latter is commonly used as an indicator for women's career orientation (e.g., Blossfeld and Huinink 1991). However, the interaction effects turned out to be insignificant.

[Table 4 about here]

\section{SUMMARY AND CONCLUDING DISCUSSION}

Given that women's emancipation and - as a consequence - their career orientation are part of an irreversible process of social, demographic, and ideational change (e.g., Lesthaeghe 1995), the compatibility of childrearing and female employment is a necessary structural condition for higher fertility rates in industrialized countries. A harmonized interplay between public policies (maternity leave or income tax regulations), work place conditions (part-time opportunities or schedule flexibility), and most importantly the availability of affordable non-parental child care should constitute such a favorable social context.

Our analysis explicitly recognizes the multilevel structure of the link between child care characteristics at the regional level and individual fertility decisions. We 
estimate the impact of the availability of day care in Kindergarten and informal care by the respondent's parents on the risk of having a first child in western Germany. While access to informal care arrangements significantly increases first birth risks, we find no effect of the availability of publicly provided child care on the transition to motherhood. Different specifications of the public day care variable and several interactions were tested, which all confirmed this result. But how can we explain the gap between the apparent conceptual significance of public day care on the one hand, and the empirical insignificance of its availability for the decision to have a first child in western Germany on the other hand?

First of all, our results might point to major shortcomings of the western German Kindergarten, such as rigid opening hours. The current institutional set-up is presumably not sufficient to foster female employment or fertility, particularly if one also considers the lack of care for infants and school-aged children (see also Kreyenfeld and Hank 2000). However, our investigation also points to difficulties in addressing the role of (public) day care empirically. In addition to the question of how to measure the quality of care, one needs to take into account the heterogeneity and dynamics of parents' child care needs (Glass and Estes 1997: 293). Children are likely to be subject to a multitude of different care arrangements (e.g., Smith 2000), which might not be adequately captured by a single quantitative indicator, such as the number of available slots in public day care. Future investigations should therefore aim at including further 'dimensions' of the child care issue in their models to obtain a broader understanding of potentially relevant factors in the relationship between children's day care and women's fertility decisions. 


\section{REFERENCES}

Ahn, N. \& Mira, P. (forthcoming). A note on the changing relationship between fertility and female employment rates in developed countries. Journal of Population Economics.

Allison, P.A. (1982). Discrete-time methods for the analysis of event histories. In S. Leinhardt (Ed.), Sociological Methodology 12 (pp. 61-98). San Francisco.

Barber, J.S., Murphy, S.A., Axinn, W.G. \& Marples, J. (2000). Discrete-time multilevel hazard analysis. In M.E. Sobel \& M.P. Becker (Eds.), Sociological Methodology 30 (pp.201-235). Washington.

Becker, G.S. (1993). A Treatise on the Family (Enlarged Edition). Cambridge.

Blau, D. M. (2001). The Child Care Problem: An Economic Analysis. New York.

Blau, D.M. \& Hagy, A.P. (1998). The demand for quality in child care. Journal of Political Economy, 106(1), 104-146.

Blau, D.M. \& Robins, P. K. (1989). Fertility, employment, and child-care costs. Demography, 26(2), 287-299.

Blossfeld, H.-P. \& Huinink, J. (1991). Human capital investments or norms of role transition? How women's schooling and career affect the process of family formation. American Journal of Sociology, 97(1), 143-168.

Brewster, K. L. \& Rindfuss, R. R. (2000). Fertility and women's employment in industrialized nations. Annual Review of Sociology, 26, 271-296.

Büchel, F. \& Spieß, C.K. (2002). Kindertageseinrichtungen und Müttererwerbstätigkeit - Neue Ergebnisse zu einem bekannten Zusammenhang. Vierteljahrshefte zur Wirtschaftsforschung, 71(1), 96-114.

Butz, W. P. \& Ward, M. P. (1979). The emergence of countercyclical U.S. fertility. American Economic Review, 69(3), 318-328. 
Casper, L. \& O’Connell, M. (1998). Work, income, and married fathers as child care providers. Demography, 35(2), 243-250.

Colberg-Schrader, H. \& Zehnbauer, A. (1996). Rechtsanspruch auf einen Kindergartenplatz. Bedarfsplanung, Notlösungen, alternative Angebote. München: Deutsches Jugendinstitut.

Conelly, R. (1992). The effect of child care costs on married women's labor force participation. The Review of Economics and Statistics, 74(1), 83-90.

Del Boca, D. (2002). The effect of child care and part time opportunities on participation and fertility decisions in Italy. Journal of Population Economics, 15(3).

DeWit, M.L. \& Ravanera, Z.R. (1998). The changing impact of women's educational attainment on the timing of births in Canada. Canadian Studies in Population, 25(1), 45-67.

Drobnic, S. (2000). The effects of children on married and lone mothers' employment in the United States and (West) Germany. European Sociological Review, 16(2), 137-157.

Ellingsæter, A.L. \& Rønsen, M. (1996). The dual strategy: motherhood and the work contract in Scandinavia. European Journal of Population, 12(3), 239-260.

Engelbrech, G. \& Jungkunst, M. (1998). Erwerbsbeteiligung von Frauen und Kinderbetreuung in ost- und westdeutschen Familien. IAB Werkstattbericht 2/98.

Ermisch, J.(1989). Purchased childcare, optimal family size and mother's employment: theory and econometric analysis. Journal of Population Economics, 2(2), 79-102.

Esping-Andersen, G. (1999). Social Foundations of Postindustrial Economies. Oxford.

Gesetz über Tageseinrichtungen für Kinder NRW (2002): Verordnung über die Höhe der Elternbeiträge nach dem Gesetz über Tageseinrichtungen für Kinder $(\$ 26,1)$, 
available at http://www.tageseinrichtungen.nrw.de.

Giannarelli, L. \& Barsimantov, J. (2000). Child Care Expenses of America's Families. Occasional Paper No. 40, The Urban Institute.

Glass, J.L. \& Estes, S.B. (1997). The family responsive workplace. Annual Review of Sociology, 23, 289-313.

Gornick, J.C., Meyers, M.K. \& Ross, K.E. (1997). Supporting the employment of mothers: policy variations across fourteen welfare states. European Journal of Social Policy, 7(1), 45-70.

Hank, K. (2002a). Regional Social Contexts and Individual Fertility Decisions: A Multilevel Analysis of First and Second Births in Western Germany. European Journal of Population, 18(4).

Hank, K. (2002b). The Differential Influence of Women's Residential District on the Risk of Entering First Marriage and Motherhood in Western Germany. MPIDR Working Paper WP 2002-027, available at www.demogr.mpg.de.

Hank, K., Tillmann, K. \& Wagner, G.G. (2001). Außerhäusliche Kinderbetreuung in Ostdeutschland vor und nach der Wiedervereinigung. Ein Vergleich mit Westdeutschland in den Jahren 1990 - 1999. Zeitschrift für Bevölkerungswissenschaft, 26(1), 55-65.

Heckman, J.J. (1974). Effects of Child-Care Programs on Women's Work Effort. Journal of Political Economy, 82(2), S136-S169.

Heckman, J. J. \& Walker, J. R. (1990). The relationship between wages and income and the timing of births: Evidence from Swedish longitudinal data. Econometrica 58(6), 1411-1441.

Hirschman, C. (1994). Why fertility changes. Annual Review of Sociology, 20, 203233.

Hoem, B. \& Hoem, J. M. (1989). The impact of women's employment on second and third births in modern Sweden. Population Studies, 43(1), 47-67. 
Hoem, B. (2000). Entry into motherhood in Sweden: the influence of economic factors on the rise and fall in fertility, 1986-1997. Demographic Research, 2(4), available at www.demographic-research.org/Volumes/Vol2/4.

Hox, J.J. \& Kreft, I.G.G. (1994). Multilevel analysis models. Sociological Methods \& Research, 22, 283-299.

Joshi, H. (1998). The opportunity costs of childbearing: More than mothers' business. Journal of Population Economics, 11(2), 161-183.

Kistler, E., Pfaff, A. B. \& Jaufmann, D. (1993). Aktuelle Daten zur Entwicklung der Kindereinrichtungen in den neuen Ländern. Es droht eine Abwärtsspirale. Arbeit und Sozialpolitik, 40(3-4), 49-54.

Knudsen, K. \& Wærness, K. (2001): National context, individual characteristics and attitudes on mothers' employment: a comparative analysis of Great Britain, Sweden and Norway. Acta Sociologica, 44(1), 67-79.

Konietzka, D. \& Kreyenfeld, M. (2002). Women's Employment and Non-Marital Childbearing: A Comparison of East and West Germany in the 1990s. Population, $57(2)$.

Kravdal, Ø. (1992). The emergence of a positive relation between education and third birth rates in Norway with supportive evidence from the United States. Population Studies, 46(3), 459-475.

Kravdal, Ø. (1996). How the local supply of day-care centers influences fertility in Norway: A parity-specific approach. Population Research and Policy Review, 15(3), 201-218.

Kreyenfeld, M. (2000). Changes in the timing of first birth in East Germany after ReUnification. Schmollers Jahrbuch, 120(2), 169-186.

Kreyenfeld, M., \& Hank, K. (2000). Does the availability of childcare influence the employment of mothers? Findings from western Germany. Population Research and Policy Review, 19(4), 317-337. 
Kreyenfeld, M., Spiess, C.K. \& Wagner, G.G. (2001). Finanzierungs- und Organisationsmodelle institutioneller Kinderbetreuung. Neuwied.

Kreyenfeld, M., Spiess, C.K. \& Wagner, G.G. (forthcoming). Kinderbetreuung in Deutschland. Zeitschrift für Erziehungswissenschaft.

Lehrer, E.L. \& Kawasaki, S. (1985). Child care arrangements and fertility: an analysis of two-earner households. Demography, 22(4), 499-513.

Lesthaeghe, R. (1995). The second demographic transition in Western countries: an interpretation. In K.O. Mason \& A-M. Jensen (Eds.), Gender and family change in industrialized countries (pp. 17-62). Oxford.

Mason, K.O. \& Kuhlthau, K. (1992). The perceived impact of child care costs on Women's Labor Supply and Fertility. Demography, 29(4), 523-543.

Merrigan, P. \& St.Pierre, Y. (1998). An econometric and neoclassic analysis of the timing and spacing of births in Canada from 1950 to 1990. Journal of Population Economics, 11(1), 29-51.

Meyers, M.K., Gornick, J.C. \& Ross, K.E. (1997). Public childcare, parental leave, and employment. In D. Sainsbury (Ed.), Gender and Welfare State Regimes (pp.117146). Oxford.

Oppenheimer, V.K. (1994): Women's rising employment and the future of the family in industrial societies. Population and Development Review, 20(2), 293-342.

Presser, H.B. (1989). Can we make time for children? The economy, work schedules, and child care. Demography, 26(4), 523-543.

Riley, L. A. \& Glass, J. L. (2002). You can't always get what you want - infant care preferences and use among employed mothers. Journal of Marriage and the Family, 64(1), 2-15.

Rindfuss, R. R. \& Brewster, K. L. (1996). Childrearing and fertility. Population and Development Review, 22 (Suppl.), 258-289. 
Rindfuss, R.R., Morgan, S.P. \& Offutt, K. (1996). Education and the changing age pattern of American fertility: 1963-1989. Demography, 33(3), 277-290.

Sainsbury, D. (1997). Taxation, family responsibilities, and employment. In D. Sainsbury (Ed.), Gender and Welfare State Regimes (pp.185-209). Oxford.

Smith, K. (2000). Who's Minding the Kids? Child Care Arrangements: Fall 1995. Current Population Reports, P70-70. U.S. Census Bureau, Washington, D.C.

SOEP Group (2001). The German Socio-Economic Panel (GSOEP) after more than 15 years - Overview. In E. Holst et al. (Eds.), Proceedings of the 2000 Fourth International Conference of German Socio-Economic Panel Study Users (GSOEP 2000) (pp.7-14), Vierteljahrshefte zur Wirtschaftsforschung, 70(1).

Spiess, K. (1998). Staatliche Eingriffe in Märkte für Kinderbetreuung. Frankfurt am Main.

Stier, H., Lewin-Epstein, N. \& Braun, M. (2001). Welfare regimes, family-supportive policies, and women's employment along the life-course. American Journal for Sociology, 106(6), 1731-1760.

Teachman, J. \& Crowder, K. (2002). Multilevel Models in Family Research: Some Conceptual and Methodological Issues. Journal of Marriage and the Family, 64(2), 280-294.

Yamaguchi, K. (1991). Event History Analysis. Newbury Park. 


\section{TABLES}

Table 1: Use of public day care in Germany 1990, 1995, 1999 (in percent of the respective age group)



Use of day care

$\begin{array}{lllllll}\text { Children } 0-3 & (6) & (6) & (7) & 62 & (21) & 34 \\ \text { Children 4-6 } & 82 & 80 & 85 & 98 & 92 & 89 \\ \text { Children 7-11 } & (2) & (3) & (5) & 35 & 27 & 24\end{array}$

\section{Use of full-time day care}

Children 4-6

$\begin{array}{llllll}21 & 15 & 20 & 80 & 60 & 56\end{array}$

Note:

(1) Parenthesis: Number of cases in the sample is less than 30.

(2) Foreigners and immigrants are excluded from the sample.

Source: GSOEP 1990, 1995, 1999; see also Hank et al. (2001).

Table 2: Supplementary child care arrangements for the youngest child in the household in 1997 (in percent)

\begin{tabular}{lcccccc}
\hline & \multicolumn{3}{c}{ Western Germany } & \multicolumn{3}{c}{ Eastern Germany } \\
Age of child & $0-3$ & $4-6$ & $7-11$ & $0-3$ & $4-6$ & $7-11$ \\
\hline
\end{tabular}

All Mothers

$\begin{array}{lcccccc}\text { Relatives } & 37 & 41 & 24 & 39 & 32 & 37 \\ \text { Friends } & 10 & 8 & 6 & 13 & 3 & 2 \\ \text { Paid care } & 5 & 6 & 5 & 3 & 0 & 1 \\ \text { No additional care } & 51 & 51 & 68 & 51 & 68 & 60\end{array}$

\section{Working Mothers}

$\begin{array}{lcccccc}\text { Relatives } & 52 & 52 & 30 & * & 49 & 40 \\ \text { Friends } & 15 & 9 & 6 & * & 5 & 2 \\ \text { Paid care } & 7 & 7 & 6 & * & 0 & 1 \\ \text { No additional care } & 29 & 38 & 60 & * & 51 & 57\end{array}$

\section{Note:}

(1) The question in the survey is: "Are there persons outside your household who regularly help take care of the child?" Multiple answers were allowed.

(2) An asterisk indicates that the sample size is too small to display meaningful results.

(3) Foreigners and immigrants are excluded from the sample.

Source: GSOEP 1997, authors' calculations. 
Table 3: Descriptive sample statistics

Mean (Stdv.)

Age

$25.1(4.0)$

\section{Education}

In education

0.17

No degree

0.18

Vocational degree

0.57

University degree

\section{Nationality}

Foreign

German

\section{Public day care (Kindergarten)}

Provision Rate (Slots per 100 children)

\section{Family network available}

Respondent's parents live in same town

Respondent's parents do not live in same town

Missing

0.18

\section{Sample size}

Number of regions (Kreise)

Number of respondents

Number of records

Number of occurrences (first births)

\section{Note:}

(1) The descriptive statistics refer to person-years of exposure.

(2) Standard deviations are not displayed for binary variables.

(3) 28 Kreise are not included in the analysis, since none of the respondents in our sample lives there.

Source: GSOEP 1984-1999 and DJI Regionaldatenbank, authors' calculations. 
Table 4: Results of (multilevel) discrete-time logistic regressions for the transition to the first child - Main model

\begin{tabular}{|c|c|c|c|c|c|c|c|c|}
\hline \multirow{3}{*}{ Intercept } & \multicolumn{4}{|c|}{ Model 1} & \multicolumn{4}{|c|}{ Model 2} \\
\hline & \multirow{2}{*}{$\begin{array}{r}\beta \\
-12.49\end{array}$} & \multirow{2}{*}{$\frac{\exp (\beta)}{0.00}$} & \multicolumn{2}{|l|}{$\mathrm{t}$} & \multirow{2}{*}{$\begin{array}{r}\beta \\
-12.84\end{array}$} & \multirow{2}{*}{$\begin{array}{r}\exp (\beta) \\
0.00\end{array}$} & \multicolumn{2}{|l|}{$\mathrm{t}$} \\
\hline & & & -8.34 & $* * *$ & & & -8.49 & $* * *$ \\
\hline \multicolumn{9}{|l|}{ Age } \\
\hline Age & 0.72 & 2.05 & 6.42 & $* * *$ & 0.74 & 2.10 & 6.59 & $* * *$ \\
\hline Age squared & -0.01 & 0.99 & -6.11 & $* * *$ & -0.01 & 0.99 & -6.24 & $* * *$ \\
\hline \multicolumn{9}{|l|}{ Nationality } \\
\hline Foreigner & 0.26 & 1.30 & 3.42 & $* * *$ & 0.31 & 1.36 & 3.77 & $* * *$ \\
\hline German & 0 & 1 & & & 0 & 1 & & \\
\hline \multicolumn{9}{|l|}{ Education } \\
\hline In education & -1.53 & 0.22 & -8.63 & $* * *$ & -1.50 & 0.22 & -8.39 & $* * *$ \\
\hline No degree & 0.25 & 1.29 & 3.05 & $* * *$ & 0.26 & 1.30 & 3.10 & $* * *$ \\
\hline Vocational degree & 0 & 1 & & & 0 & 1 & & \\
\hline University degree & -0.15 & 0.86 & -1.24 & & -0.14 & 0.87 & -1.09 & \\
\hline \multicolumn{9}{|l|}{ Public day care } \\
\hline Provision rate & 0.20 & 1.22 & 1.06 & & 0.11 & 1.12 & 0.51 & \\
\hline \multicolumn{9}{|l|}{ Family network } \\
\hline Parents in town & 0.18 & 1.20 & 2.53 & $* * *$ & 0.19 & 1.21 & 2.64 & $* * *$ \\
\hline Parents not in town & 0 & 1 & & & 0 & 1 & & \\
\hline \multicolumn{9}{|c|}{ Regional random effect } \\
\hline$\sigma_{u}$ & -- & & & & 0.29 & & & $* *$ \\
\hline Log likelihood & \multicolumn{4}{|c|}{$-3,576$} & & \multicolumn{2}{|c|}{$-3,569$} & \\
\hline
\end{tabular}

Note:

(1) Significance: $*<.10 ; * *<.05 ; * * *<.01$

(2) Coefficient of public day-care variable is multiplied by 100.

(3) Flag variables for missing information on woman's family network were added to the regression.

Source: GSOEP 1984-1999 and DJI Regionaldatenbank, authors' calculations. 


\section{APPENDIX}

Table A1: Results of (multilevel) discrete-time logistic regressions for the transition to the first child - Model specifying public day care as binary variable

Model $3 \quad$ Model 4

\begin{tabular}{lrrrrrrll} 
& $\beta$ & $\exp (\beta)$ & $\mathrm{t}$ & $\beta$ & $\exp (\beta)$ & $\mathrm{t}$ & \\
\hline Intercept & -12.25 & 0.00 & -8.21 & $* * *$ & -12.61 & 0.00 & -8.37 & $* * *$
\end{tabular}

Age

Age

Age squared

2.00

$6.20 * * *$

$0.71 \quad 2.04$

$6.35 * * *$

$-0.01$

$0.99-5.87 \quad * * *$

$-0.01$

$0.99-5.99 \quad * * *$

Nationality

Foreigner

German

$\begin{array}{cc}0.28 & 1.33 \\ 0 & 1\end{array}$

$3.65 * * *$

$\begin{array}{cc}0.32 & 1.38 \\ 0 & 1\end{array}$

$3.94 * * *$

\section{Education}

In education

No degree

Vocational degree

University degree

$\begin{array}{rlrlrcrr}-1.47 & 0.23 & -8.25 & * * * & -1.44 & 0.24 & -8.06 & * * * \\ 0.26 & 1.29 & 3.06 & * * * & 0.27 & 1.30 & 3.11 & * * * \\ 0 & 1 & & & 0 & 1 & & \\ -0.11 & 0.90 & -0.86 & & -0.10 & 0.91 & -0.76 & \end{array}$

Public day care

below 95\%

95\% and more

$\begin{array}{rlrlrrr}0 & 1 & & & 0 & 1 & \\ 0.17 & 1.18 & 2.33 & * * & 0.13 & 1.14 & 1.53\end{array}$

Family network

Parents in town

Parents not in town

$\begin{array}{rlrrrrrr}0.45 & 1.57 & 6.45 & * * * & 0.46 & 1.59 & 6.43 & * * * \\ 0 & 1 & & & 0 & 1 & & \end{array}$

\section{Regional random effect}

$\sigma_{u}$

$0.28 * *$

Log likelihood $-3,556$ $-3,550$

Note:

(1) Significance: $*<.10 ; * *<.05 ; * * *<.01$

(2) Flag variables for missing information on woman's education and for family network were added to the regression.

Source: GSOEP 1984-1999 and DJI Regionaldatenbank, authors' calculations. 
Table A2: Results of (multilevel) discrete-time logistic regressions for the transition to the first child - Model with set of binary indicators representing various threshold levels of child care provision

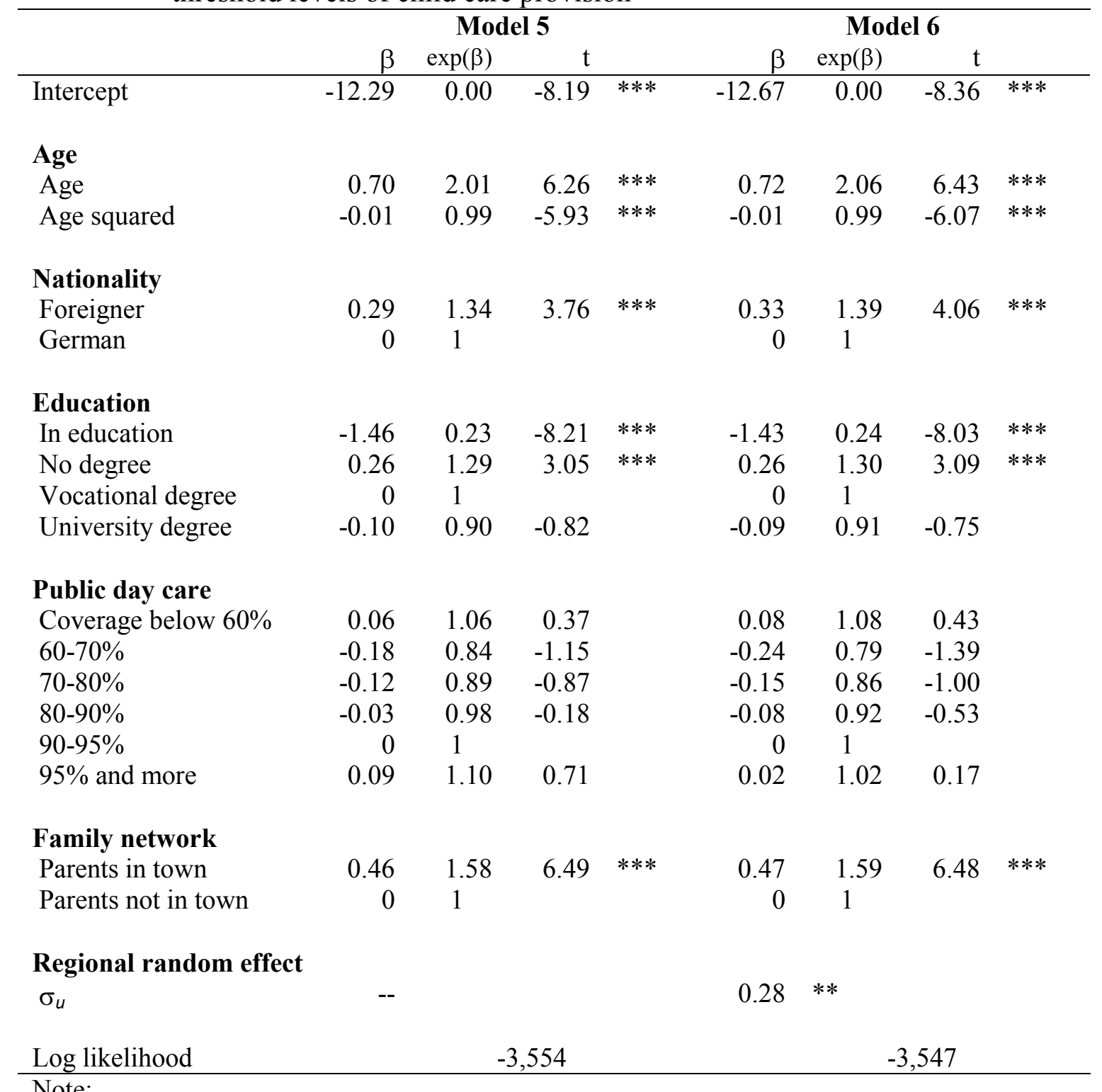
Note:

(1) Significance: $*<.10 ; * *<.05 ; * * *<.01$

(2) Flag variables for missing information on woman's education and for family network were added to the regression.

Source: GSOEP 1984-1999 and DJI Regionaldatenbank, authors' calculations. 
Table A3: Results of multilevel discrete-time logistic regression for the transition to the first child - Interaction model 'public day care (binary)' and 'family network'

\begin{tabular}{lrrrl}
\hline & \multicolumn{5}{c}{ Model 7 } & & \\
& $\beta$ & $\exp (\beta)$ & $\mathrm{t})$ & \\
\hline Public day care \& family network & 0.70 & 2.01 & 6.11 & $* * *$ \\
No public day care \& family network & 0.33 & 1.39 & 4.03 & $* * *$ \\
Public day care \& no family network & -0.10 & 0.91 & -0.87 & \\
No public day care \& no family network & 0 & 1 & & \\
\hline
\end{tabular}

\section{Note:}

This table only displays the interaction effects. The full model additionally contains the woman's age and age squared, her education and nationality, and a regional random effect.

Source: GSOEP 1984-1999 and DJI Regionaldatenbank, authors' calculations.

Table A4: Results of multilevel discrete-time logistic regression for the transition to the first child - Interaction model 'public day care (binary)' and 'woman's education'

\begin{tabular}{lrrrll}
\hline & \multicolumn{3}{c}{ Model 8 } & & \\
& $\beta$ & $\exp (\beta)$ & $\mathrm{t}$ & \\
\hline No public day care \& no degree & 0.39 & 1.48 & 2.35 & $* *$ \\
No public day care \& vocational degree & 0.12 & 1.13 & 0.84 & \\
No public day care \& university degree & 0 & 1 & & & \\
Public day care \& no degree & 0.52 & 1.68 & 2.68 & $* * *$ \\
Public day care \& vocational degree & 0.25 & 1.29 & 1.55 & \\
Public day care \& university degree & 0.24 & 1.27 & 0.89 & \\
\hline
\end{tabular}

\section{Note:}

This table only displays the interaction effects. The full model additionally contains the woman's age and age squared, her nationality, a family network indicator, and a regional random effect.

Source: GSOEP 1984-1999 and DJI Regionaldatenbank, authors' calculations.

Table A5: Results of multilevel discrete-time logistic regressions for the transition to the first child - Interaction model 'family network' and 'woman's education'

\begin{tabular}{lrrrl}
\hline & \multicolumn{3}{c}{ Model 9 } & \\
& $\beta$ & $\operatorname{Exp}(\beta)$ & $\mathrm{t}$ & \\
\hline No family network \& no degree & 0.29 & 1.34 & 1.62 & \\
No family network \& vocational degree & 0.04 & 1.04 & 0.28 & \\
No family network \& university degree & 0 & 1 & & \\
Family network \& no degree & 0.80 & 2.23 & 4.39 & $* * *$ \\
Family network \& vocational degree & 0.52 & 1.67 & 3.23 & $* * *$ \\
Family network \& university degree & 0.34 & 1.41 & 1.43 & \\
\hline
\end{tabular}

Note:

This table only displays the interaction effects. The full model additionally contains the woman's age and age squared, her nationality, a public day care indicator, and a regional random effect.

Source: GSOEP 1984-1999 and DJI Regionaldatenbank, authors' calculations. 